\title{
Mantle metasomatism and alkali carbonatite silicate phase reaction as inferred by Nyerereite inclusions in Vulture volcano carbonatite rocks.
}

\author{
Francesco Stoppa ${ }^{1}$, Victor. V. Sharygin ${ }^{2}$, Adrian P. Jones ${ }^{3}$ \\ ${ }^{1}$ Dipartimento di Scienze della Terra, Università G.d'Annunzio, Chieti, Italy, \\ ${ }^{2}$ Institute of Geology and Mineralogy, RAS, Novosibirsk, Russia, \\ ${ }^{3}$ Department of Earth Sciences, University College London, UK. (fstoppa@unich.it)
}

Italian volcanic $\mathrm{CO}_{2}$, mofetes and associated volcanic features

Central-southern Italy emit $2.5-5 \times 10^{11} \mathrm{~mol}^{-\mathrm{a}^{-1}}$ of deep $\mathrm{CO}_{2}$ with Vulture volcano alone producing $3.7 \times 10^{6}$ $\mathrm{mol} \mathrm{a} \mathrm{a}^{-1} \mathrm{~km}^{-2}$ of $\mathrm{CO}_{2}$. The mefite d'Ansanto, located 30 $\mathrm{km} \mathrm{W-SW}$ of Vulture, emits $\sim 300,000$ ton/year of $\mathrm{CO}_{2}$, which is comparable to the whole of the Taupo volcanic field in New Zealand or the geothermal fields in Iceland. Most of the Italian $\mathrm{CO}_{2}$ has a $\delta^{13} \mathrm{C}_{\mathrm{Ctot}}$ between 2 and $-2 \%$ vs PDB indicating a mantle/magmatic contribution. In the last 2 m.y., the Italian lithosphere has experienced a rapid thinning but thermal flow is low indicating adiabatic mantle cooling. This is more suggestive of volatile expansion as opposed to a high degree of partial melting and also fits well with of ultralkaline magmatism. Intense $\mathrm{CO}_{2}$ flowing in the diatremes leaves a distinctive agglomerate produced by fluidisation of carbonatitic melt and ultramafic debris. The highly explosive release at the surface of such an amalgam produces a distinctive volcanic morphology, the maar, surrounded by a thin apron of lapilli ash tuff. The lapilli are peculiar displaying spin, layered internal structure and are cored with a mantle nodule. In general, they have inner layers made of melilitite and outer layers made of agglutinated, smaller porphyritic carbonatite lapilli.

\section{Vulture extrusive carbonatites}

At the Vulture, there are 7 major diatremes which extend beyond of the main volcanic edifice and are about $130 \mathrm{ka}$ old. Mt. Vulture extrusive carbonatites contain large xenocrysts of $\mathrm{Cr}$-hastingsite, $\mathrm{Cr}$ phlogopite, Cr-diopside, akermanitic melilite and forsterite. Groundmass consists of calcite, clinopyroxene, apatite, zoned Ti-magnetite with MnMg-rich rim, perovskite with $\mathrm{Nb}$-rich rim and rare titanite. The occurrence of associated lherzolites indicates that the primary magma segregated from the mantle rock at about 22 kbar. The highest crystallization temperature recorded by melt inclusions in olivine is $1240^{\circ} \mathrm{C}$. Major oxides show high silica (16-24wt\%). Mantle-normalized bulk rock geochemistry shows negative spikes of HFSE (e.g. NbTaan Zr-Hf) and high LREE/HREE fractionation (Fig.
$1 \mathrm{~A}$ and $\mathrm{B}$ ). Negative spikes of $\mathrm{Nb}-\mathrm{Ta}$ and $\mathrm{Zr}$-Hf are very typical of worldwide carbonatites, both intrusive and extrusive. More evolved carbonatites with lower $\mathrm{Mg \#}\left(\mathrm{Mg} / \mathrm{Mg}+\mathrm{Fe}^{2+}\right.$ at.), lower compatible element contents and few mantle debris, have higher LREE/HREE and greater $\mathrm{HFSE}^{4+} / \mathrm{HFSE}^{3+}$ fractionation (i.e. $\mathrm{Nb}-\mathrm{Ta} / \mathrm{Zr}+\mathrm{Hf}$ ). HFSEs having larger ionic radius are lesser fractionated but $U$ and $T h$ values are particularly high at the Vulture.
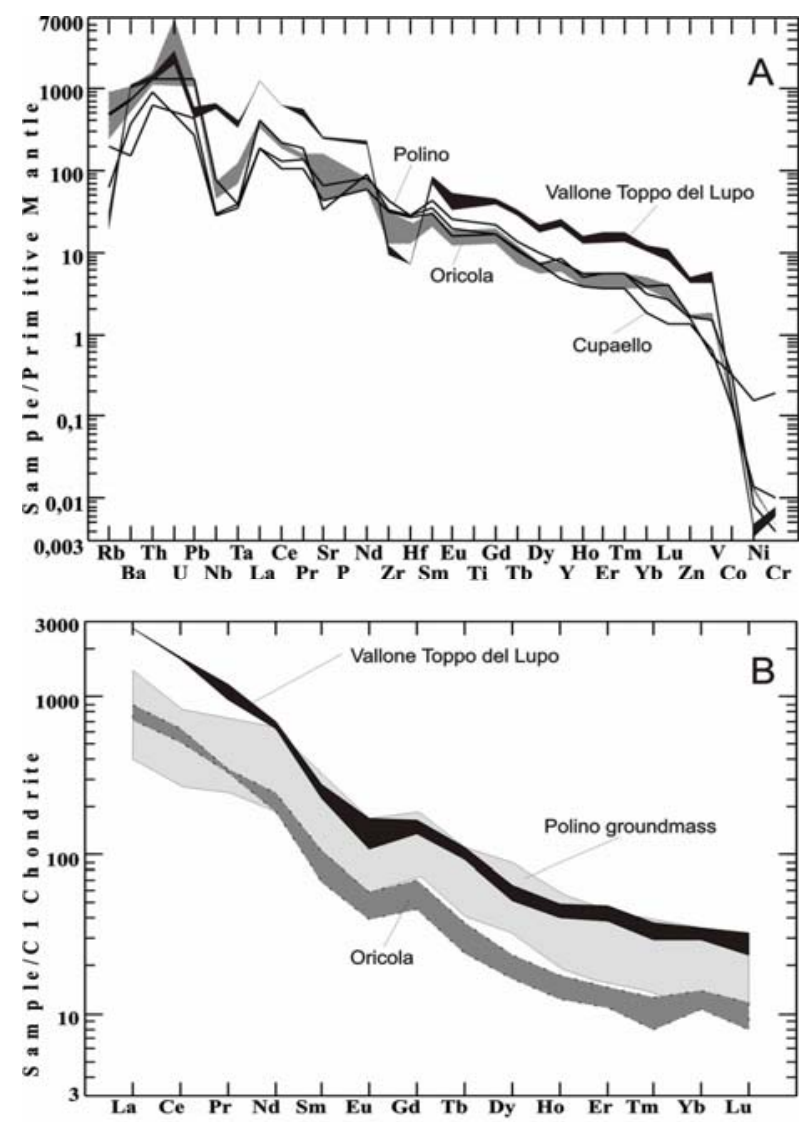

Fig.1 A and B. Normalised abundance of incompatible and compatible elements in Italian carbonatites

Some other minor differences observed among HFSE ratios may be the result of the slightly different solubilities of HFSE in the parental magma, which is 
most likely to be a carbonatitic foiditic/melilititic melt. Unaltered carbonatites has $\delta^{13} \mathrm{C}_{(\%) \text { PDB }}$ between -8 and 4 Rosatelli et al., 2000).

\begin{tabular}{|c|c|c|c|c|}
\hline locality & Polino & Cupaello & Oricola & Vulture \\
\hline$\overline{\mathrm{SiO}_{2}}$ & 16.0 & 18.1 & 24.7 & 16.8 \\
\hline $\mathrm{TiO}_{2}$ & 0.51 & 0.37 & 0.38 & 0.54 \\
\hline $\mathrm{Al}_{2} \mathrm{O}_{3}$ & 3.90 & 2.51 & 10.45 & 5.81 \\
\hline $\mathrm{Fe}_{2} \mathrm{O}_{3}$ & 3.65 & 2.25 & 4.91 & 6.28 \\
\hline $\mathrm{FeO}$ & 1.31 & 0.12 & 1.30 & 1.3 \\
\hline $\mathrm{MnO}$ & 0.07 & 0.04 & 1.19 & 0.48 \\
\hline $\mathrm{MgO}$ & 7.31 & 7.83 & 1.12 & 1.52 \\
\hline $\mathrm{CaO}$ & 38.3 & 34.3 & 27.5 & 36.6 \\
\hline $\mathrm{Na}_{2} \mathrm{O}$ & 0.05 & 0.03 & 1.47 & 0.42 \\
\hline $\mathrm{K}_{2} \mathrm{O}$ & 0.49 & 1.01 & 4.18 & 0.29 \\
\hline $\mathrm{P}_{2} \mathrm{O}_{5}$ & 0.59 & 0.82 & 0.28 & 2.30 \\
\hline $\mathrm{CO}_{2}$ & 24.0 & 25.6 & 19.6 & 19.55 \\
\hline LOI & 2.93 & 6.59 & - & 5.25 \\
\hline Total & 99.1 & 99.6 & 97.1 & 97.2 \\
\hline $\mathrm{Rb}$ & 26.0 & 81.5 & 186 & 18.7 \\
\hline $\mathrm{Pb}$ & 31.0 & 50 & 129 & 65.5 \\
\hline $\mathrm{U}$ & 9.0 & 5.3 & 76.5 & 51.9 \\
\hline Th & 59.0 & 41 & 72.8 & 86.7 \\
\hline $\mathrm{Ba}$ & 3181 & 789 & 2945 & 6050 \\
\hline $\mathrm{Nb}$ & 20.0 & 17 & 25.0 & 349 \\
\hline $\mathrm{Ta}$ & 0.9 & 0.9 & 0.9 & 9.4 \\
\hline $\mathrm{La}$ & 111 & 88.9 & 170 & 637 \\
\hline $\mathrm{Ce}$ & 232 & 166 & 316 & 1095 \\
\hline $\mathrm{Sr}$ & 1824 & 1295 & 2395 & 6955 \\
\hline $\operatorname{Pr}$ & 28.2 & 21.1 & 30.7 & 104 \\
\hline $\mathrm{Nd}$ & 113 & 71.5 & 88.4 & 310 \\
\hline $\mathrm{Sm}$ & 22.2 & 12.3 & 10.4 & 40.1 \\
\hline $\mathrm{Zr}$ & 345 & 201 & 104 & 96.8 \\
\hline $\mathrm{Hf}$ & 8.0 & 7.95 & 6.0 & 2 \\
\hline $\mathrm{Eu}$ & 4.7 & 2.305 & 2.7 & 9.11 \\
\hline $\mathrm{Gd}$ & 15.8 & 12.2 & 9.5 & 31.5 \\
\hline $\mathrm{Tb}$ & 1.7 & 0.9 & 1.1 & 3.9 \\
\hline Dy & 7.5 & 5.6 & 5.0 & 15.2 \\
\hline $\mathrm{Y}$ & 38.0 & 14 & 20.0 & 82.7 \\
\hline Ho & 1.0 & 0.7 & 0.7 & 2.6 \\
\hline $\mathrm{Er}$ & 2.6 & 1.7 & 1.9 & 7.2 \\
\hline $\mathrm{Tm}$ & 0.3 & 0.2 & 0.2 & 0.9 \\
\hline $\mathrm{Yb}$ & 1.5 & 0.79 & 1.9 & 5.7 \\
\hline $\mathrm{Lu}$ & 0.2 & 0.09 & 0.3 & 0.7 \\
\hline $\mathrm{Ni}$ & 308 & 29 & 27.0 & 4.4 \\
\hline $\mathrm{Cr}$ & 501 & 33.5 & 16.0 & 22 \\
\hline
\end{tabular}

Tab.1. Whole rock analyses of selected Italian carbonatites

Carbonate mantle nodules, metasomatism and mineral inclusions

Spinel lherzolite, wherlite and phlogopitite nodules are re-equilibrated to lithospheric mantle pressures but contain rare relicts of $\mathrm{Cr}-\mathrm{Mg}$ garnet, indicating a deeper origins. Detailed analyses on 300 xenoliths from Mt. Vulture have confirmed that 20\% contain carbonate. Mantle nodules host calcite globules often linked by menisci-necks and are composed of a mosaic of 2-20 $\mu \mathrm{m}$ crystals, with varying optical orientation. Some of these globules contain liquid/gaseous $\mathrm{CO}_{2}$ bubbles and are pierced by quenched microphenocrysts of silicate phases. The carbonate composition varies from calcite to $\mathrm{Mg}$-calcite (3.8-5.0 wt\% $\mathrm{MgO}$ ) both within the carbonate globules and from globule to globule. These features are consistent with formation from a quenched calciocarbonatite melt suggesting that the enrichment of the lithospheric mantle in incompatible trace elements and LREE may be caused by the infiltration of such a melt.

Reaction between carbonatite melt and peridotite have been studied in detail in the Vulture nodules and it has been suggested that this could be produced by a percolating alkaline-carbonatite metasomatising a previous pyrope harzburgite mantle. Formation of the immiscible silicate-carbonatite liquids occurred via immiscibility during melt ascension. Na-Ca-carbonate with $\mathrm{Na} / \mathrm{K}=2.3$ and sensible $\mathrm{SO}_{3}$ from Vulture carbonatite resembles chemically nyerereite $\mathrm{Na}_{2} \mathrm{Ca}\left(\mathrm{CO}_{3}\right)_{2}$ from natrocarbonatite lavas of the Oldoinyo Lengai volcano. It was found together with Ca-silicate in polymineral inclusion in melilite xenocryst, evidencing about possible appearance of alkali carbonatite melt in magmatic system beneath the Vulture volcano.

\begin{tabular}{lrrrr} 
Phase & \multicolumn{1}{l}{ Nye } & \multicolumn{1}{l}{ Nye } & \multicolumn{1}{l}{ Nye } & \multicolumn{1}{l}{ Nye } \\
$\mathrm{FeO}$ & 0.18 & 0.18 & 0.17 & 0.14 \\
$\mathrm{MnO}$ & 0.02 & 0.01 & 0.08 & 0.00 \\
$\mathrm{MgO}$ & 0.15 & 0.12 & 0.15 & 0.15 \\
$\mathrm{CaO}$ & 32.9 & 32.9 & 33.1 & 33.2 \\
$\mathrm{Na} 2 \mathrm{O}$ & 18.5 & 18.5 & 18.8 & 18.6 \\
$\mathrm{~K}_{2} \mathrm{O}$ & 4.39 & 4.84 & 4.58 & 4.47 \\
$\mathrm{SrO}$ & 1.96 & 1.99 & 1.91 & 1.9 \\
$\mathrm{P}_{2} \mathrm{O}_{5}$ & 0.39 & 0.39 & 0.39 & 0.39 \\
$\mathrm{SO}_{3}$ & 4.91 & 4.67 & 4.29 & 4.86 \\
$\mathrm{Total}$ & 63.3 & 63.6 & 63.5 & 63.7
\end{tabular}

Tab. 2 nyerereite identificative analyses from inclusions in melilite

It is suggested that reaction between pyrope harzburgite and alkali carbonatite melt could explain metasomatism in the source of the Italian carbonatite melts. Formation of the immiscible silicate-carbonatite liquids occurred during melt ascension. The carbonatite melt coexisting with alkali silicate melt should contain substantial amounts of alkalis and the appearance of nyerereite in melilite supports this hypothesis. However, considering the rarity of alkali carbonates in the IUP carbonatites we postulate that alkalis could be consumed at crustal pressure by the crystallization of foids in foiditic melilitite and potassium feldspar in phonolites and/or be dissolved in fluids separating during eruption. The high $\mathrm{Ca}$ contents and carbonate inclusions in most Mg-rich olivine phenocrysts found in Italian carbonatites and kamafugites indicate that high $\mathrm{Ca}$ is a primary characteristic of Italian mantle melts. The composition of mantle melts has been characterized by primary high $\mathrm{K}_{2} \mathrm{O}, \mathrm{Na}_{2} \mathrm{O}, \mathrm{F}, \mathrm{Cl}$ and $\mathrm{S}$ contents, which are inherited by all later derivatives. This rules out any crustal assimilation of carbonate, chlorides or sulphates. The conditions of the initial magma crystallization during its ascension towards the surface has been estimated from the results of 
thermometric experiments with melt and fluid inclusions and mantle nodules as proxy geobarothermometers. Primary silicate-carbonate inclusions in calcite were also reported from the Mt. Vulture sövite. Their carbonate component is dominated by dolomite. The carbonate melt coexisting with alkaline silicate melt should contain substantial amounts of alkalis and neyrereite has been found in melilite and apatite inclusions. However, considering the rarity of alkali carbonates in IUP carbonatites we postulate that alkalies could be consumed at crustal pressure by the crystallization of foids in kamafugites and potassium feldspar in phonolites and/or be dissolved in aqueous fluid separating during eruption.

\section{Geochemical and geodynamic characteristics}

Italian carbonatite and melilitite/foidite are co-eruptive conjugate pairs and it has been demonstrated that there is no dilution by sedimentary limestone or any other crustal assimilation. The geochemistry of $\mathrm{Zr}-\mathrm{Hf}$, Ta$\mathrm{Nd}$, Ti depends on the differing solubility of these elements in alkaline/peralkaline melts and therefore have different geochemical behaviour with respect to basaltic melts. This was already noted and others, who discredited the tectonic classification ability of popular diagrams based on HFSE ratios for non basaltic, cratonic and potassic rocks. Italian carbonatites and conjugate silicate rocks have $\mathrm{C}, \mathrm{O}$ and $\mathrm{B}$ isotope ratios ranging from typical mantle values to enriched heavy isotope values which disprove the derivation of carbonatitic melts from a crustal reservoirs. However, by plotting $\mathrm{Sr}, \mathrm{Nd}$ and $\mathrm{Pb}$ isotopic ratios for IUP rocks it is possible to detect a relationship between two separate mantle end-members: FOZO and ITEM. Any involvement of sedimentary limestones can be discharged, as those are much less radiogenic than ITEM. Furthermore, addition of crustal material is in disagreement with high $\mathrm{Cr}+\mathrm{Ni}$ content, strongly silica undersaturated character, peralkalinity and, in general, with the geochemistry of comagmatic kamafugitecarbonatite pair. Mantle melts associated with subduction do not have an ITEM or FOZO component, which appears to dispose the hypothesis of an origin of IUP carbonatitites by subduction adopted by some. ITEM is a highly radiogenic reservoir which may be located outside the main convective mantle. It is accepted that the deep mantle that remains isolated for a time scale of over a billion years would allow for the radioactive decay of light nuclides such as K. Light nuclides are a likely, volatile component which exsolves slowly during cooling and contraction of the outer core. Several observations suggest it is likely that $\mathrm{C}$ (and other light elements) were incorporated into the Earth's core during accretion. Graphite and carbides are commonly present in iron meteorites and this is consistent with the dissolution of $\mathrm{C}$ into Fe-Ni liquids. The carbon isotopic composition of graphite in iron meteorites exhibits a uniform value of $-5 \%$. identical to the mode in the distribution found in diamonds, carbonatites and oceanic basalts. If there is $\mathrm{C}$ (and $\mathrm{K}$ $\mathrm{Rb}$ ) in the core, which is not reached by subduction there is no point making the deep $\mathrm{C}$ evolution more complex by involving shallower Earth layers. Movement of heavy carbon towards the surface is simple when differentiation of the inner part of the planet takes place over billions of years. If FOZO is representative of a common asthenospheric reservoir then the ITEM isotopic characteristics can be related to the hypothesised ' $D$ ' layer of the mantle as on the Earth it doesn't exist any other similar reservoir. To date, Italian carbonatites and melilitites have always been associated with continental lithospheric thinning. However, plume models have long been proposed for Italy but plume size and composition have as yet been poorly addressed. More recently, the existence of a very large plume confined to the transition layer beneath the Central Mediterranean Sea, Azores-Canary area and continental Europe, has been suggested. Plume head expansion in the mantle would produce an asynchronous mosaic of extending areas and extensive mantle metasomatism driven by a general eastward mantle flow. Most of the rare ultralkaline rocks found in the Central Mediterranean sea and the active volcanoes can be explained from fingers emitted by the degassing plume head or simply by metasomatised sublithospheric mantle melting during lithosphere thinning.

\section{Conclusions}

In our opinion there is nothing about Italian carbonatites and their tectonic setting to lead us to consider them as exceptional to other worldwide carbonatites. There is very strong evidence that Italian mantle was invaded by carbonatitic melts (alkaline?) and that mantle minerals reacted to form a complex metasomatic assemblage. Fluid inclusion studies indicate that pristine parental magma was rich in $\mathrm{CaO}$ and $\mathrm{CO} 2$ and that carbonatite-silicate immiscibility occurred over a wide range of $\mathrm{T} / \mathrm{P}$ conditions. Extrusive carbonatites have not been found in any subduction environment either oceanic or continental. This is too much of a coincidence to be ignored. Theories concerning the generation of carbonatite in a subduction environment would need a more robust cause-effect demonstration. Therefore, it is felt that Italian carbonatites need to be interpreted in a larger geological context which can include the recent discovery of large extrusive carbonatites in Spain and France which are remote from subduction in time and space.

Complete reference list for this extended abstract can be find in:

Stoppa F., (2007). CO2 magmatism in Italy: from deep carbon to carbonatite volcanism. In: Alkaline Magmatism: its source and plume (N.Vladikyn Ed), IGC, Irkutsk, 109-126

Woolley R Alan. and Kjarsgaard A. Bruce (2008). Carbonatite occurrences of the world: map and database. Geological Survey of Canada, Open File 5796. 
